\title{
RADIKALISME ISLAM DAN UPAYA DERADIKALISASI PAHAM RADIKAL
}

\author{
Abu Rokhmad \\ Unversitas Diponegoro Semarang \\ e-mail: abu_rokhmad@yahoo.com
}

\begin{abstract}
Educational institutions are supposedly not immune from the influence of radical ideology. This research concluded that: (1) Some teachers acknowledged that the concept of radical Islam may have been spread among students because of their lack of religious knowledge; (2) The units of Islamic study in the schools is progressing well but there is no guarantee of immune from radicalism since most of the learning process is released to a third sides; (3) In the textbooks and worksheets there are various statements that may encourage students to hate other religions and other nations. It can be concluded that the strategy of deradicalization may be implemented are preventive deradicalization and preservative deradicalization of moderate Islam, andcurative deradicalization.

$* * *$

Lembaga-lembaga pendidikan diduga tidak kebal terhadap pengaruh ideologi radikal. Penelitian ini menyimpulkan bahwa: (1) Beberapa guru mengakui adanya konsep Islam radikal yang mungkin menyebar di kalangan siswa karena kurangnya pengetahuan keagamaan; (2) Unit-unit kajian Islam di sekolahsekolah berkembang baik namun tidak ada jaminan adanya kekebalan dari radikalisme karena proses belajarnya diserahkan kepada pihak ketiga; (3) Di dalam buku rujukan dan kertas kerja terdapat beberapa pernyataan yang dapat mendorong siswa untuk membenci agama atau bangsa lain. Dapat disimpulkan bahwa ada beberapa strategi deradikalisasi yang dapat diimplementasikan yaitu deradikalisasi preventif, deradikalisasi preservatif terhadap Islam moderat, dan deradikalisasi kuratif.
\end{abstract}

Keywords: radikalisme, PAI, deradikalisasi

Walisongo, Volume 20, Nomor 1, Mei 2012 


\section{A. Pendahuluan}

Pasca reformasi yang ditandai dengan terbukanya kran demokratisasi telah menjadi lahan subur tumbuhnya kelompok Islam radikal. ${ }^{1}$ Fenomena radikalisme di kalangan umat Islam seringkali disandarkan dengan paham keagamaan, sekalipun pencetus radikalisme bisa lahir dari berbagai sumbu, seperti ekonomi, politik, sosial dan sebagainya.

Radikalisme yang berujung pada terorisme menjadi masalah penting bagi umat Islam Indonesia dewasa ini. Dua isu itu telah menyebabkan Islam dicap sebagai agama teror dan umat Islam dianggap menyukai jalan kekerasan suci untuk menyebarkan agamanya. Sekalipun anggapan itu mudah dimentahkan, namun fakta bahwa pelaku teror di Indonesia adalah seorang Muslim garis keras sangat membebani psikologi umat Islam secara keseluruhan.

Keterlibatan berbagai pihak dalam menangani masalah radikalisme dan terorisme sangat diharapkan. Tujuannya adalah untuk mempersempit ruang gerak radikalisme dan terorisme, serta kalau perlu menghilangkan sama sekali. Dalam konteks di atas, peran sekolah dan lembaga pendidikan sangat penting dalam menghentikan laju radikalisme Islam.

Pendidikan dan lembaga pendidikan sangat berpeluang menjadi penyebar benih radikalisme dan sekaligus penangkal (baca: deradikalisasi) Islam radikal. Studi-studi tentang radikalisme dan terorisme mensinyalir adanya lembaga pendidikan Islam tertentu (terutama yang nonformal, seperti pesantren) telah mengajarkan fundamentalisme dan radikalisme kepada para peserta didik. Belakangan, sekolah-sekolah formal juga mulai mengajarkan elemen-elemen Islam radikal, misalnya mengajarkan kepada murid untuk tidak menghormat bendera Merah Putih saat upacara bendera. ${ }^{2}$

\footnotetext{
${ }_{1}^{1}$ Menurut Fealy dan Hooker: Radical Islam refers to those Islamic movement that seek dramatic change in society and the state. The comprehensive implementation of Islamic law and the upholding of 'Islamic norms', however defined, are central elements in the thinking of most radical groups. Radical Muslims tend to have a literal interpretation of the Qur'an, especially those sections relating to social relations, religious behavior and the punishment of crimes, and they also seek to adhere closely to the perceived normative model based on the example of the Prophet Muhammad. Greg Fealy and Virginia Hooker (ed.), Voices of Islam in Southeast Asia: A Contemporary Sourcebook, (Singapore: ISEAS, 2006), h. 4.

2 www.metrotvnews.com, "Dua Sekolah Larang Siswa Hormat Bendera". Berita ini dimuat pada 6 Juni 2011, terkait dua sekolah (SMP Al-Irysad Tawangmangu dan SD Al-Albani Matesih) berbasis agama yang melarang siswa menghormat Bendera Merah Putih di Karanganyar .
} 
Sejalan dengan menjamurnya ormas-ormas Islam pasca reformasi, pendidikan (tarbiyah) dianggap pintu efektif bagi penyebaran dakwah Islam. Kini, lahir ribuan pendidikan Islam terpadu (jenjang PAUD, TK hingga SLTA) yang didirikan oleh ormas-ormas Islam tertentu dari berbagai jenjang pendidikan. Ormas-ormas Islam itu memiliki ciri keagamaan tertentu yang 'berbeda' dengan yang lain. Ciri-ciri keagamaan yang mereka anut adalah: (1) Khas Islam Timur Tengah; (2) Leterlek dan harfiah dalam memahami Islam; (3) Mengenalkan istilah-istilah baru yang bernuansa Arab seperti, halaqah, dawrah, mabit dan seterusnya.

Siswa/siswi sekolah menengah atas (SMA/SMK) digarap serius oleh ormas-ormas Islam yang bercirikan seperti di atas. Moment dawrah, halaqah dan mabit di satu sisi sangat positif dan membantu kerja guru agama untuk menanam akidah dan syariat Islam. Namun di sisi lain, model Islam yang diajarkan cenderung mendorong peserta didik untuk tidak toleran terhadap pihak lain.

Hasil penelitian yang dilakukan oleh Lembaga Kajian Islam dan Perdamaian (LaKIP) Jakarta sungguh mengejutkan. Penelitian yang dilakukan antara Oktober 2010 hingga 2011 terhadap guru PAI dan siswa (SMP dan SMA) di Jabodetabek menunjukkan bahwa 49 \% siswa setuju dengan aksi radikalisme demi agama. Oleh karena itu, guru-guru PAI memiliki peran strategis untuk menanamkan Islam moderat dan dapat menemukan cara yang tepat untuk menanggulangi (deradikalisasi) Islam radikal. Penelitian radikalisme Islam di sekolah umum ini sangat penting dilakukan karena beberapa alasan.

Pertama, kurikulum PAI beserta standar isi dan kompetensinya sangat dipengaruhi oleh kecenderungan paham yang diajarkan oleh para guru kepada para siswa. Oleh karenanya, guru dituntut dapat mengajarkan Islam dengan cara yang tidak mendorong peserta didik untuk menjadi radikal.

Kedua, siswa/siswi SMA yang tidak memiliki background pendidikan agama (pesantren) sangat mudah terpengaruh oleh model-model Islam harfiah yang diajarkan oleh guru atau ustadz mereka. Oleh karena itu, pihak sekolah dan guru agama perlu menjalin kerjasama dengan ormas-ormas Islam yang dikenal mengajarkan Islam moderat. Hal ini penting supaya anak didik memiliki wawasan yang luas tentang paham keislaman dari berbagai sumber. 
Ketiga, pihak sekolah dan guru perlu meningkatkan kemampuan untuk deteksi dini (early warning) peserta didik yang mulai 'menyimpang' dari keumuman paham keislaman yang ada. Siswa-siswi yang mulai "sok alim," menyendiri atau ekslusif dengan kelompok sendiri, gampang mengharamkan dan mengkafirkan, mengikuti pengajian berhari-hari tanpa izin, mengikuti pengajian yang di dalamnya ada baiat, fanatik, menyerang kelompok Islam lain, mulai berani kepada guru dan orang tua, memiliki cita-cita jihad dan mendirikan negara Islam, adalah sebagian kecil tanda-tanda yang harus diwaspadai oleh guru-guru PAI. Dengan mengenali sumber radikalisme di sekolah, akan ditemukan upaya deradikalisasi dapat berjalan efektif manakala pihak sekolah dan guru PAI dapat memainkan peran positif dengan mengajarkan Islam moderat.

Pokok masalah yang dikaji meliputi dual hal. Pertama, bagaimanakah elemen-elemen radikalisme Islam dalam pembelajaran PAI pada Sekolah Menengah umum (SMU)? dan Kedua, bagaimanakah strategi deradikalisasi Islam para guru dalam pembelajaran PAI pada Sekolah Menengah Umum (SMU)?

\section{B. Elemen Radikalisme Islam dalam Pembelajaran PAI}

Pada dasarnya, perlu dibedakan antara radikal, radikalisme dan radikalisasi. Menurut KH. Hasyim Muzadi (ketua PBNU dan pengasuh pesantren al-Hikam Malang), yang ditemui pada saat mengisi seminar nasional "Deradikalisasi Agama melalui Peran Muballigh di Jawa Tengah"3, pada dasarnya seseorang yang berpikir radikal (maksudnya berpikir mendalam, sampai ke akar-akarnya) boleh-boleh saja, dan memang berpikir sudah seharusnyalah seperti itu. Katakanlah misalnya, seseorang yang dalam hatinya berpandangan bahwa Indonesia mengalami banyak masalah (ekonomi, pendidikan, hukum, dan politik) disebabkan Indonesia tidak menerapkan syariat Islam. Dan oleh karena itu, misalnya, dasar Negara Indonesia harus diganti dengan sistem pemerintahan Islam (khilāfah islāmiyyah). Pendapat yang radikal seperti itu sah-sah saja.

3 Seminar diselenggarakan oleh Fakultas Dakwah IAIN Walisongo bekerja sama dengan Direktorat Jenderal Informasi dan Komunikasi Publik Kementerian Komunikasi dan Informasi, tanggal 20 Juli 2011 di Hotel Novotel Semarang. 
Sekeras apapun pernyataan di atas jika hanya dalam wacana atau pemikiran, tidak akan menjadi persoalan publik. Sebab pada hakikatnya, apa yang muncul dalam benak atau pikiran tidak dapat diadili (kriminalisasi pemikiran) karena tidak termasuk tindak pidana. ${ }^{4}$ Kejahatan adalah suatu tindakan (omissi). Dalam pengertian ini, seseorang tidak dapat dihukum hanya karena pikirannya, melainkan harus ada suatu tindakan atau kealpaan dalam bertindak.

Sedangkan radikalisme, masih menurut Muzadi, adalah radikal dalam paham atau ismenya. Biasanya mereka akan menjadi radikal secara permanen. Radikal sebagai isme ini dapat tumbuh secara demokratis, force (kekuatan) masyarakat dan teror. ${ }^{5}$ Dengan kata lain, radikalisme adalah radikal yang sudah menjadi ideologi dan mazhab pemikiran. Dalam pandangan peneliti, setiap orang berpotensi menjadi radikal dan penganut paham radikal (radikalisme), tergantung apakah lingkungan (habitus) mendukungnya atau tidak.

Sedangkan yang dimaksud dengan radikalisasi, menurut Muzadi adalah (seseorang yang) tumbuh menjadi reaktif ketika terjadi ketidakadilan di masyarakat. Biasanya radikalisasi tumbuh berkaitan dengan ketikadilan ekonomi, politik, lemahnya penegakan hukum dan seterusnya. Jadi, jangan dibayangkan ketika teroris sudah ditangkap, lalu radikalisme hilang. Sepanjang keadilan dan kemakmuran belum terwujud, radikalisasi akan selalu muncul di masyarakat. Keadilan itu menyangkut banyak aspek, baik aspek hukum, politik, pendidikan, sosial, hak asasi, maupun budaya. Hukum itu berbeda dengan keadilan. Hukum adalah aspek tertentu, sedangkan keadilan adalah akhlak dari hukum itu

Potensi berpikir, bersikap dan bertindak radikal, berideologi radikal (radikalisme) dan tumbuh reaktif menjadi radikal (radikalisasi) adalah modal awal seseorang menjadi pelaku teror (teroris) atau orang yang berpaham teror (terorisme). Tidak ada teror tanpa radikalisme. Sebaliknya penganut radikalisme belum tentu menyukai jalan kekerasan (teror). Sekalipun demikian,

4 Tindak pidana, disebut pula peristiwa pidana atau delik, adalah tindakan seseorang yang memenuhi rumusan undang-undang, bersifat melawan hukum dan dilakukan oleh orang yang dapat dipertanggungjawabkan. Kepada seseorang yang telah memenuhi rumusan tersebut dapat dijatuhkan pidana. Siti Soetami, Pengantar Tata Hukum Indonesia, (Bandung: Eresco, 1992), h. 54.

${ }^{5}$ KH. Hasyim Muzadi, tanggal 20 Juli 2011 di Hotel Novotel Semarang. 
terdapat kesamaan bahasa yang digunakan oleh radikalisme maupun terorisme, yaitu bahasa militan atau bahasa perjuangan (language of militance). ${ }^{6}$

Dalam konteks penelitian ini, potensi berpikir, bersikap dan bertindak radikal itu disederhanakan dalam bentuk rumusan elemen-elemen radikalisme dalam pembelajaran PAI pada SMU. Ada dua sumber primer yang menjadi acuan pada bagian ini, yaitu pandangan guru tentang proses pembelajaran PAI, dan materi pembelajaran PAI yang ada dalam buku paket dan lembar kerja siswa (LKS). Dalam penelitian ini, hanya satu contoh buku paket dan 5 LKS dari penerbit berbeda dari kurikulum 2006.

\section{Pandangan Guru-guru PAI}

Ketika ditanyakan tentang dugaan sekolah-sekolah umum mulai dipengaruhi paham-paham Islam radikal, jawaban guru-guru PAI pada SMU di Semarang dapat dikategorikan menjadi tiga bagian.

Pertama, sebagian besar guru PAI (6 guru dari 9 guru yang diwawancarai) mengakui adanya potensi penyebaran virus radikalisme di kalangan siswasiswi SMU. Abdul Aziz, guru PAI SMA Sultan Agung mengatakan:

"Ya, bisa jadi. Gerakan-gerakan (Islam radikal yang) mempengaruhi anak-anak muda itu mungkin terjadi. Hal itu biasanya terjadi di sekolahsekolah umum yang doktrin agamanya masih lemah dan menjalankan ajaran agama secara mentah. (Para guru) memasukkan (paham-paham) radikal kepada siswa SMA yang masih dangkal pemahamannya tentang Islam. Bisa juga (disebabkan karena) memahami dalil al-Qur'an hanya parsial, sepotong-potong, dan tidak menyeluruh, (misalnya, memahami ayat) ashiddāu 'alā al-kuffār, keras terhadap orang kafir (secara sepotong)."

Menurut Hidayatul Azizah (guru PAI SMA 14 Semarang), memang kebanyakan anak yang berpikir radikal adalah siswa dari sekolah umum. Mereka kebanyakan tidak memiliki dasar agama yang kuat sehingga mudah dipengaruhi dengan paham agama yang harfiah dan instan. Sri Istiqomah juga mengakui kemungkinan pengaruh paham radikal pada anak-anak SMU disebabkan kurangnya pendidikan agama sehingga memudahkan mereka membaca buku (bertema) Islam yang radikal.

${ }^{6}$ Muhammad Ali, Teologi Pluralis-Multikultural, (Jakarta: Kompas, 2003), h. 119. 
Siti Nur Rohmah membetulkan dugaan pengaruh radikalisme di kalangan pelajar SMU. Hal demikian terjadi disebabkan kurangnya pelajaran agama di sekolah. Hal ini mendorong mereka (untuk menambah pengetahuan agamanya) dengan membaca buku-buku agama dan mengikuti tambahan (ekstra) kegiatan keagamaan di dalam maupun di luar sekolah. Buku-buku yang dibaca dan kegiatan keagamaan yang diikuti mungkin lebih keras ajarannya sehingga mempengaruhi paham peserta didik ketika berinteraksi di sekolah.

Menurut guru PAI di SMA 7 Semarang (Budi dan seorang lainnya yang tidak mau disebut namanya), indikasi ke arah dugaan sekolah umum mulai dipengaruhi oleh paham-paham Islam radikal memang ada. Hal itu dapat dilihat dari (sikap) para siswa yang menyerang (ofensif) bila ajaran (yang disampaikan guru) tidak sesuai dengan poin-poin dasar (fundamental) agama.

Kata 'menyerang' di atas menarik untuk dianalisis lebih jauh karena tampak inline dengan karakter keras dalam paham Islam radikal. Menyerang dalam pengertian lisan sudah menjadi sifat dasar Islam radikal. Mereka suka menyerang paham dan amalan orang lain di luar kelompok mereka sebagai bid'ah, kafir dan syirik. Di dalam sikap 'menyerang' itu sebenarnya muncul sikap kritis tetapi harfiah. Umumnya kelompok Islam selalu mempertanyakan apakah sebuah amalan misalnya, adakah sumber hukumnya dari alQur'an atau hadits? Jika ada dan itu shahih berarti harus dilaksanakan. Sebaliknya, bila dalilnya dianggap ada tetapi menurut mereka berkualitas daif (lemah), biasanya mereka akan menyerangnya dengan kata-kata ahli bid'ah. Mereka menyerang jauh lebih keras jika mendapati Muslim lain mengamalkan suatu ajaran dan menurut mereka sama sekali tidak ada dasar hukumnya, biasanya mereka akan melabeli dengan kata-kata syirik atau musyrik.

Kedua, seorang guru menolak dugaan adanya sekolah umum yang mulai dipengaruhi paham-paham Islam radikal. Secara tegas, Ahmad Dhuha, guru PAI SMU Kesatrian, menolak sinyalemen di atas.

"Pandangan umum, sekolah umum mendapatkan stigma demikian saya tidak setuju, tidak sepakat. Mereka (Islam radikal) dalam menyampaikan ajaran (dilakukan) secara tidak terbuka. (Sasaran ajaran mereka adalah kepada) seseorang (yang) bimbang dan agak galau (sehingga mau menerima ajaran yang kurang tepat). Kalau kayak sampeyan (yang memiliki dasar-dasar ilmu agama yang kuat), sudah kebal (tidak mempan) diajarkan kayak begitu, pasti gagal. Model perekrutan (Islam radikal) itu (bersifat) personal, tidak terbuka, bukan pula kelembagaan, tapi ia mempunyai semacam jaringan." 
Ketika ditanyakan lebih lanjut, apakah dalam pembelajaran PAI diselipkan wacana soal radikalisme? Ahmad Dhuha menjelaskan:

“Ajaran itu kan (berisi) contoh yang nyata. (Seseorang) harus mencontohkan perilaku terpuji dan (menghindari perilaku) tercela. Misalnya, orang itu mengaku Islam kemudian ia mengebom kepada orang-orang yang itu juga Islam. (Sesama Muslim) tidak boleh dianiaya. (Seperti kata Nabi Muhammad SAW dalam sebuah sabdanya): barang siapa memerangi kafir dzimmi berarti memerangi saya. Saya tidak pernah menyampaikan kepada anak-anak selain itu. Tidak ada sisipan (paham radikal, kecuali) hanya memperjelas keterangan sebagai contoh saja."

Ketiga, dua orang guru PAI mengaku tidak tahu atau tidak tegas menjawab soal dugaan adanya sekolah umum yang mulai dipengaruhi pahampaham Islam radikal, dengan dua model jawaban. Yang pertama menyatakan tidak tahu karena di sekolahnya tidak ada (penyebaran paham Islam radikal). Seandainyapun ada (penyebaran paham tersebut), tapi tidak kelihatan. Jawaban ini diwakili oleh Abas, guru PAI SMK Negeri 2 Semarang. Maftuhatun Nikmah, guru PAI dari SMA 5 Semarang menyatakan perlu diwaspadai adanya penyebaran paham radikal di kalangan siswa SMU. Oleh karena itu, edukasi dan sosialisasi ajaran Islam yang benar dan moderat perlu terusmenerus dilakukan.

Untuk menambah wawasan ilmu keislaman di tengah minimnya jam pelajaran PAI di sekolah, pada umumnya pihak sekolah menyambut baik berbagai kegiatan keagamaan siswa/siswi. Sebagian kegiatan keagamaan diinisiasi oleh guru agama dan para murid sendiri, sedangkan sebagian yang lain merupakan prakarsa dari pihak lain, misalnya dari ormas keagamaan, lembaga dakwah atau pribadi-pribadi yang peduli terhadap dakwah Islam. Masing-masing memberi label kegiatan keagamaannya dengan sebutan atau nama yang khas.

Ormas Islam seperti NU misalnya, menyebut kegiatan keagamaan bagi siswa-siswa dengan sebutan pesantren kilat (sanlat). Belakangan istilah ini lazim dipakai oleh sekolah-sekolah untuk menyebut kegiatan keagamaan pada masa liburan. Muhammadiyah juga memiliki jenis kegiatan keagamaan di sekolah umum dengan nama yang khas, misalnya, selain sanlat juga dikenal istilah "Darul Arqam Dasar" (DAD).

Setelah Indonesia memasuki era reformasi dan lahir berbagai ormas/ orpol kegamaan baru, juga menjadikan siswa-siswi SMU sebagai sasaran 
dakwah. Yang paling menonjol misalnya, Hizbut Tahrir Indonesia (HTI) dan Partai Keadilan Sejahtera (PKS). Mereka ini juga mengenalkan jenis kegiatan keagamaan dengan nama yang unik dan menarik, seperti mabit (semacam kegiatan perkemahan dengan nuansa Islam yang kuat), dawrah (pelatihan intensif tentang keislaman) dan halaqah (kajian-kajian keislaman).

Terkait dengan penyelenggaran kegiatan kerohanian Islam, seluruh informan menyatakan ada di sekolah masing-masing, seperti "sanlat" di bulan Ramadhan, tarawih dan peringatan hari besar Islam (PHBI). Dua orang informan menyebutkan secara khusus bentuk kegiatan keagamaan di sekolah mereka, yaitu mabit dan dawrah. Kuliah Ahad Pagi juga diselenggarakan di dua sekolah.

Semua informan menyatakan bahwa di sekolah mereka tidak ada kegiatan keagamaan yang mengharuskan pesertanya untuk melakuat baiat (sumpah setia). Jawaban ini dapat dipahami bila kegiatan keagamaan dilakukan di dalam lingkungan sekolah. Oleh karenanya, perlu penelitian lebih lanjut untuk membuktikan apakah baiat ada atau tidak, terutama terhadap kegiatan mabit yang mengharuskan siswa-siswa keluar dari lingkungan sekolah dan menginap di suatu tempat.

Guru adalah salah satu aspek penting dalam pembelajaran PAI, baik secara formal maupun nonformal. Oleh karena pembelajaran PAI banyak berkaitan dengan doktrin-doktrin agama, maka informasi tentang latar belakang pendidikan dan afiliasi organisasi sosial-politik dari pengisi acara pengajian di sekolah sangat penting dilakukan. Hal ini dimaksudkan untuk menghindari pengaruh paham keagamaan yang dibawa oleh pengisi acara kegiatan terhadap para siswa.

Seluruh informan menyatakan bahwa pengisi acara dalam kegiatan keagamaan di SMU adalah guru PAI sendiri dan sebagian berasal dari luar sekolah. Jika pengisi acara kegiatan berasal dari guru PAI sendiri, mereka mengaku mengenal secara dekat. Namun bila pengisi kegiatan keagamaan berasal dari luar, mereka mengaku tidak kenal dan atau tahu tapi tidak lengkap. 5 orang informan mengaku tahu latar belakang pendidikan dan sosial-keagamaan pengisi acara keagamaan siswa, baik dari dalam maupun dari luar sekolah. 1 orang informan mengaku tidak tahu dan 3 informan lainnya mengaku tahu tetapi tidak lengkap. 
Terkait dengan materi yang diajarkan kepada siswa dalam kegiatan keagamaan, sebagian besar informan (6 informan) mengaku tidak ada bedanya atau sama dengan ajaran yang biasa diamalkan oleh umumnya umat Islam. Namun dua orang informan menyatakan bahwa ajaran Islam yang disampaikan sebagian sama dan sebagian tidak.

Pertanyaan yang berhubungan dengan 'kegemaran' mengoreksi akidah orang lain dengan label ahli bid'ah atau kafir juga diajukan. Menurut pengamatan guru-guru PAI, tidak gejala semacam itu di sekolah mereka. Pertanyaan seperti ini dimaksudkan untuk mengantisipasi model ajaran yang ofensif atau menyerang terhadap kelompok lain yang dianggap berbeda.

Termasuk yang menjadi elemen radikalisme adalah mempertentangkan antara Islam dengan Indonesia, misalnya dalam bentuk menolak hormat terhadap simbol Negara bendera merah. Peneliti bertanya kepada para informan apakah dalam kegiatan keagamaan siswa ada pengisi acara yang mengajarkan soal keharaman menghormat bendera. Seluruh informan menyatakan tidak ada ustadz yang mendorong siswa tidak menghormati simbolsimbol Negara.

Pertanyaan seperti di atas menarik ditanyakan karena preseden ada lembaga pendidikan Islam di Karanganyar Jawa Tengah diberitakan mengharamkan siswa-siswinya hormat kepada bendera Merah Putih. Menurut kepala sekolah setempat, hormat bendera sama artinya dengan syirik (menyekutukan Tuhan). Peneliti mencurigai, masih banyak lembaga pendidikan Islam (dengan ideologi Islam tertentu) yang bersikap serupa. Bahkan oknum kader parpol Islam besar disinyalir pernah menginjak-injak bendera Merah Putih dalam suatu acara partai.

Agak mengherankan, mengapa seorang Muslim taat tidak bisa membedakan antara menghormat dengan menyembah. Bukankah sikap hormat itu biasa dilakukan oleh semua orang, baik hormat kepada orang tua, guru, maupun hormat kepada simbol dan lambang, seperti lambang sekolah, lambang partai, dan lambang Negara.

Semangat berIslam yang käffah, tidaklah berarti harus merusak bangunan kebangsaan dan kenegaraan. Dimana pun seorang Muslim berada, ia pasti bisa menjadi Muslim yang kaffah. Hukum Islam bisa tegak di manamana, baik di negara Islam maupun non-Islam. Menegakkan Syariat Islam tidak harus dengan mendirikan negara Islam. Sebab negara itu wașilah 
(sarana), bukan ghāyah (tujuan). Jika suatu negara menjamin dan melindungi kebebasan umat Islam dalam beribadah, sejatinya ia adalah negara Islam yang wajib dihormati.

Disadari atau tidak, Indonesia sudah menjadi pasar raya ideologi. Kegagalan pemerintah mewujudkan kesejahteraan hanya akan mempermudahkan masyarakat untuk merubah ideologinya. Semua ideologi yang ada dianggap gagal membahagiakan manusia. Oleh karena itu, ideologi alternatif dikampanyekan terus untuk menggugah dan memprovokasi pikiran masyarakat. Ideologi alternatif itu dipilih dan bersumber dari agama agar kebenarannya tidak bisa dibantah dan pelakunya mendapat legitimasi teologis yang final.

Jika pengusung ideologi NII merasa cukup kuat untuk merealisasikan cita-citanya, bagaimanapun caranya mereka pasti akan mengganti ideologi Pancasila. Oleh karenanya, negara tidak boleh membiarkan ideologi yang akan mengancam bangunan Indonesia. Inilah pentingnya menghidupkan kembali falsafah hidup bangsa Indonesia (Pancasila) sebagai pengikat komitmen kebangsaan.

Bangsa ini mestinya jujur menghadapi kenyataan bahwa Indonesia bukanlah negara agama. Bangunan seperti ini sudah disepakati oleh seluruh penganut agama di awal kemerdekaan. Pancasila dianggap falsafah negara yang mengayomi seluruh agama dan menjadi pengikat kesatuan dan persatuan bangsa. Inilah yang harus menjadi komitmen bersama seluruh elemen bangsa agar tidak mengganti Pancasila dengan ideologi lain. Keindonesiaan dan keislaman jangan dipertentangkan terus-menerus di hadapan publik. Sejatinya, keduanya dapat berjalan harmonis dan rukun tanpa saling mematika.

\section{Bahan Ajar}

Untuk level Sekolah Menengah Atas (SMA) ada tiga buku ajar Pendidikan Agama Islam (PAI) untuk masing-masing kelas yang berbeda satu sama lain. Untuk kelas X digunakan buku Pendidikan Agama Islam yang disesuaikan dengan kompetensi yang akan dicapai pada kelas tersebut. Hal yang sama juga berlaku di kelas X dan XI.

Ada banyak penulis yang tertarik untuk membahas kurikulum Pendidikan Agama Islam tahun 2006 dan menulisnya menjadi buku ajar. Di antara yang menulis buku paket Pendidikan Agama Islam adalah Mugy Nugraha, M.S.I., Milki Aan, S.Pd.I dan Erta Wahyudin, M.Pd.I. Mereka menulis 
bahan ajar untuk kelas X, XI dan XII SMA yang diterbitkan oleh Karya Toha Putra Semarang.

\section{a. Bahan Ajar Kelas X}

\section{1) Buku untuk Semeser Pertama}

Buku untuk kelas X ini disusun berdasarkan kurikulum tahun 2006 dan menjelaskan enam standar kompetensi: 1) Memahami ayat-ayat al-Qur'an; 2) Memahami ayat-ayat al-Qur'an tentang keikhlasan beribadah; 3) Meningkatkan keimanan kepada Allah SWT, melalui pemahaman sifat-sifat-Nya dalam Asma'ul-Husna; 4) Membiasakan perilaku terpuji, 5) Memahami sumber hukum Islam, hukum taklifi dan hukum wad'iy; dan 6) Memahami keteladanan Rasulullah. Untuk masing-masing standar kompetensi dijelaskan bahan ajar yang bersumber ayat al-Qur'an maupun yang lain.

Untuk standar kompetensi yang pertama, memahami ayat-ayat al-Qur'an tentang manusia dan tugasnya sebagai khaliffah di bumi, diuraikan ayat-ayat alBaqarah [2]: 30, al-Mu'minun [23]: 12-14, al-Dzariyat [51]: 56 dan al-Nahl [16]: 78. Siswa diharapkan dapat membaca, mengartikan dan berperilaku sebagai khaliffah di bumi seperti dijelaskan dalam ayat-ayat di atas.

Bab ini menguraikan tiga ayat yang dipilih dan dirasa terkait tentang manusia dan tugasnya sebagai khalifah di bumi. Pertama siswa belajar tentang bagiamana cara membaca tiga ayat al-Qur'an tersebut. Setelah itu, secara berturut-turut siswa diajak untuk memahami arti dari masing ayat-ayat, dengan menunjukkan terjemahan seluruh arti ayat yang dimaksud kemudian menunjukkan arti perungkapan. Tidak hanya sampai di situ, penulis memberikan penjelasan dari ayat yang dikutip. Dalam upaya menjelasan surat alBaqrah [2]: 30 ini, penulis mengutip ayat 61 dari surat Hud seraya menjelaskan bahwa "tugas pokok manusia sebagai khalifah adalah mengolah bumi untuk diperoleh manfaatnya bagi kehidupan manusia itu sendiri secara berkelanjutan."7

${ }^{7}$ Mugy Nugraha, Milki Aan, dan Erta Wahyudin, Pendidikan Agama Islam, untuk kelas X SMA, (Semarang: Karya Toha Putra), h. 7. 
Hanya saja penulis melanjutkan uraiannya yang bisa dilihat sangat menguntungkan kelompok Islam dan merugikan yang lain dengan pernyataannya:

"Dari satu sisi, penugasan tersebut dapat merupakan pelimpahan kekuasaan politik kepada manusia. Di sisi lain karena yang menjadikan dan menugaskan itu adalah Allah SWT., maka para petugas dalam menjalankan tugasnya harus memperhatikan kehendak dan aturan yang memberi tugas."

Kalimat di atas dapat diartikan bahwa memang seperti itu tugas seorang khalīfah di bumi. Akan tetapi bisa juga diartikan bahwa aturan itu adalah aturan Allah sebagaimana suatu kelompok itu memahaminya. Jika pilihan jatuh pada yang kedua ini, maka akan kurang menguntungkan bagi mereka yang pemahannya beda dengan suatu kelompok tersebut, apabila mereka hidup bersama-sama dengan yang lain.

Uraian berikutnya membahas tentang hakikat manusia dengan menjelaskan ayat 12-14 surat al-Mu'minun. Seperti penjelasan pada ayat 30 surat al-Baqarah, penulis menjelaskan tentang tajwìd, dilanjutan dengan terjemahan dan penjelasan arti untuk masing-masing penggalan ayat. Setelah itu dijelaskan kandungan arti ayat tersebut bahwa "jin dan manusia diciptakan Allah untuk mengabdi kepada-Nya; bentuk pengabdian ('ibādah), ada yang maḥ̣ah dan ada yang ghair maḥdah; Allah hanya bisa menerima yang baik dan indah dari hamba-Nya.

Untuk standar kompetensi kedua, memahami ayat-ayat al-Qur'an tentang keikhlasan beribadah, dibahas ayat-ayat al-An'am: 162-163, dan alBayyinah: 5. Kompetensi dasar yang ingin dicapai adalah bahwa siswa mampu membaca, mengartikan dan menampilkan perilaku ikhlas beribadah seperti terkandung dalam tiga ayat tersebut di atas.

Penulis memulai uraiannya dengan bahasan tentang tajwìd, dilanjutkan dengan terjemahan ayat dan arti kata yang dipilih. Selanjutnya penulis menguraikan tentang arti ayat-ayat tersebut secara keseluruhan dan mengakhiri bahasan dengan uraian tentang kandungan ayat dan perilaku yang patut dicontoh. Dalam penjelasannya, penulis menyebutkan bahwa:

${ }^{8}$ Ibid. 


\begin{abstract}
"Ayat tersebut dari segi redaksional terkait dengan Ahli Kitab, yaitu orang Yahudi dan Nasrani. Mereka disuruh Allah untuk shalat dan membayar zakat, sebab itulah cara beragama yang benar. Tetapi mereka menyimpang dan menyekutukan Allah, padahal mereka sudah mengetahui perintah-perntah itu dari isi kitab-kitab yang mereka miliki yaitu kitab Taurat dan Injil."9
\end{abstract}

Selanjutnya penulis menyatakan bahwa "Orang Yahudi dan Nasrani adalah tipe manusia yang suka menentang perintah Allah."10 Pernyataan tersebut adalah arti dari ayat-ayat al-Qur'an yang dikutip, yakni al-An'am [6]: 162-163. Hanya saja arti tersebut jika dibawa di luar konteks ayat terebut akan melahirkan persoalan terkait dengan hubungan antar pemeluk agama, karena image negatif yang mungkin dapat terbangun di benak siswa.

Berbeda dengan bahan ajar untuk standar kompetensi pertama dan kedua, untuk standar kompensi ketiga ini dibahas sifat-sifat Allah SWT dalam Asma'ul-Husna. Standar kompensi yang diharapkan adalah meningkatkan keimanan kepada Allah SWT melalui pemahaman sifat-sifat-Nya dalam Asmā'ul-Husnā, siswa diharapkan dapat menyebutkan 10 sifat Allah, menjelaskan arti dari 10 sifat Allah tersebut dan berperilaku yang mencerminkan keimanan terhadap 10 sifat Allah dalam Asmā' al-Husnā.

Iman adalah meyakini kebenaran dalam hati, mengikrarkan keyakinan itu dengan ucapan dan merealisasikannya dalam perbuatan" (h. 34). Sebenarnya sifat-sifat Allah yang baik ini tidak hanya diketahui dan dihafal tapi hendaknya menjadi contoh dalam perilaku manusia. Oleh karena itu, penulis menjelaskan bahwa untuk menjadi orang beriman, siswa perlu mengetahui setidaknya 10 sifat-sifat Allah sebagaimana disebutkan dalam Asma al-Husna. Sifat-sifat tersebut adalah: (1) al-Raḥmān, (2) al-Raḥim, (3) al-Quddūs, (4) alSalām, (5) al-Nāfi', (6) al-'Adlu, (7) al-Ghaffār, (8) al-Hakīm, (9) al-Hafiz, dan (10) al-Malik. Untuk menjelaskan arti dari masing-masing 10 sifat Allah SWT, penulis mengutip ayat-ayat yang terkait.

Perilaku mukmin yang mencerminkan 10 sifat Allah SWT dalam Asmä al-Husnā adalah: (1) Selalu berbuat baik dan saling berkasih sayang; (2) Bertakwa dan menjadi pribadi yang penyayang; (3) Menjaga kesucian dan menjaga diri dan orang lain; (4) Berusaha menjadi pribadi yang adil dan

\footnotetext{
${ }^{9}$ Ibid., h. 27.

10 Ibid., h. 27.
} 
bijaksana; (5) Berusaha menjadi pribadi yang bermanfat bagi orang lain; (6) Berusaha menjadi pemimpin yang baik; dan (7) Berusaha menjadi pribadi yang pemaaf.

Untuk mencapai standar kompetensi keempat, membiasakan prilaku terpuji, siswa diharapkan dapat menyebutkan pengertian husnu al-ẓan (berbaik sangka), menyebutkan contoh-contoh perilaku husnu al-ẓan, baik terhadap Allah SWT, diri sendiri dan sesama manusia, serta membiasakan perilaku husnu al-ẓan dalam kehidupan sehari-hari.

Cara husnu al-ẓan kepada Allah SWT adalah syukur dan sabar. Sedangkan husnu al-zan kepada diri sendiri adalah adanya rasa percaya diri serta gigih dan ulet. husnu al-ẓan terhadap sesama manusia diwujudkan dengan barbaik sangka kepada yang lain.

Untuk bahan ajar standar kompetensi kelima, yaitu memahami sumber hukum Islam, hukum taklifiy dan hukum wad'iy, dibahas tentang fungsi alQur'an, hadits dan ijtihad dalam sumber hukum Islam. Siswa setelah mengikuti pelajaran ini diharapkan dapat menyebutkan pengertian sumber hukum Islam, kedudukan, fungsi hukum taklifiy dan hukum wad'iy dalam hukum Islam. Setelah itu diharapkan pula siswa dapat menerapkan hukum taklifiy dan hukum wad'iy dalam kehidupan sehari-hari.

Dalam bab ini penulis menjelaskan pengertian al-Qur'an, al-Hadits dan ijtihad sebagai sumber hukum Islam. Uraian mengenai sumber hukum Islam ini didasarkan pada al-Qur'an dan al-Hadits Nabi Muhammad. Selanjutnya penulis membahas tentang hukum taklifiy, yaitu hukum perbuatan yang wajib dilakukan dan perbuatan yang dialarang dan harus ditinggalakan. Hukum taklifiy ini dibagi menjadi lima: wajib, sunnah, haram, makruh dan mubah.

Bahan ajar tentang bagaimana cara memahami keteladanan Rasulullah dalam membina umat di Makkah adalah sejarah dakwah Rasulullah SAW pada periode tersebut. Selain siswa mampu memahami bagaimana cara berdakwah, siswa juga diharapkan mampu mendeskripsikan substansi dan strategi dakwah Rasulullah SAW pada periode tersebut.

Bahasan dalam bab ini adalah tentang sejarah dakwah Nabi Muhammad SAW. Nabi Muhammad menerima wahyu dan kemudian berdakwah di kalangan keluarga dekat saja dan setelah itu Nabi Muhammad memulai dakwah secara terang-terangan. Banyak tantangan yang harus dihadapi oleh Nabi Muhammad dan pengikutnya. Selama periode Makkah ini hanya sedikit yang bersedia pengikut Nabi Muhammad. 


\section{2) Buku untuk Semester Kedua}

Standar kompetensi yang akan dicapai dalam buku ajar ini adalah: (7) Memahami ayat al-Qur'an tentang demokrasi; (8) Meningkatkan iman kepada malaikat; (9) Membiasakan perilaku terpuji; (10) Menghindari perilaku tercela; (11) Memahami hukum Islam tentang zakat, haji, dan wakaf; dan (12) Memahami keteladanan Rasulullah dalam membina umat periode Madinah.

Untuk standar (7), kompetensi dasar yang ingin dicapai adalah siswa mampu membaca dan mengartikan Ali Imran ayat 159 dan al-Syura ayat 38, dan dapat menampilkan perilaku hidup demokratis sesuai dengan kandungan dua ayat tersebut. Penulis memulai uraiannya dengan bahasan tajwìd tentang hukum bacaan ayat 159 dari surat al-Nahl. Bahasan dilanjutkan dengan terjemah dan mengartikan penggalan ayat. Kemudian penulis menguraikan penjelasan dan kandungan ayat tersebut. Hal serupa juga dilakukan pada ayat 38 dari surat al-Syura. Dalam rangkuman dari uraian bab VII ini penulis menyatakan bahwa:

a. Di dalam al-Qur'an terdapat petunjuk bagi setiap Muslim, khususnya bagi setiap pemimpin agar bermusyawarah dengan anggota-anggotanya.

b. Untuk bermusyawarah dengan baik, semua pihak yang ditunjuk sebagai ketua dalam acara musyawarah dan yang menjadi anggota atau peserta, harus bersikap lemah lembut, menghargai dan menghormati hak dan kewajiban orang lain.

c. Masalah-masalah yang bisa dimusyawarhkan adalah masalah yang terkait dengan urusan mu'amalah, sementara masalah akidah dan ibadah sudah jelas petunjuknya baik dari al-Qur'an maupun dari Hadits Nabi.

d. Dalam melakukan musyawarah, ada beberpa prinsip yang harus dipedomani oleh para peserta musyawarah, antara lain; tidak boleh melakukan musyawarah untuk hal-hal yang dilarang agama dan tidak untuk memilih pemimpin bagi kaum Muslimin yang bukan Muslim.

Pandangan penulis pada point terakhir bahwa "tidak boleh bermsyawarah untuk memilih pemimpin bagi kaum Muslimin yang bukan Muslim" ini didasarkan pada ayat 51 surat al-Maidah. Ayat tersebut diartikan sebagai berikut: 
"Wahai orang-orang yang beriman, janganlah kamu menjadikan orangorang Yahudi dan Nasrani teman setia(mu), mereka satu sama lain saling melindungi. Barangsiapa di antara kamu menjadikan mereka teman setia, maka sesungguhnya dia termasuk golongan mereka."

Di atas merupakan salah satu terjemah dari ayat tersebut. Terjemahan yang dikeluarkan oleh Departemen Agama agak berbeda dengan ini. Persoalan lain dengan menjadikan ayat ini sebagai rujukan untuk tidak boleh menjadikan orang yang bukan Muslimin sebagai pemimpin adalah diskriminatif ${ }_{2}$ jika tanpa menyebutkan kepemimipinan apa yang dimaksudkan. Dalam batas tertentu, pemahaman atas ayat di atas dapat memicu kebencian terhadap kelompok agama lain.

\section{b. Bahan Ajar Kelas XI}

Buku yang diperuntukkan bagi siswa kelas XI ini juga dibagi menjadi dua. Bagian awal untuk semester pertama dan bagian akhir untuk semester kedua. Sub bab ini akan menjelaskan kandungan dari buku untuk kelas XI dan mendiskusikan hal-hal yang bisa dianggap memotivasi radikalisme.

Standar kompetensi ke-13 adalah tentang tarikh. Pada bab XIII penulis menjelaskan perkembangan Islam pada masa modern yang diawali pada tahun 1800 sampai sekarang. Penulis menjelaskan juga tentang timbulnya gerakan Islam modern. Dalam bab XIII ini penulis menjelaskan pembaharuan Islam di bidang akidah, ilmu pengetahuan, dan bidang politik.

Terdapat uraian menarik tentang sejarah perkembangan Islam ini yang terkait dengan kemungkinan munculnya radikalisme yang berakar pada sikap anti-Barat. Penulis menyebutkan bahwa kemunduran Islam diakibatkan oleh pengaruh kebudayaan Barat. Simak pernyataan penulis yang mungkin dapat memicu lahirnya sikap radikalisme:

"Faktor lain yang mempengaruhi kemunduran umat Islam saat ini yaitu adanya pengaruh kebudayan Barat. Pengaruh tersebut banyak ditiru oleh para pemuda Islam tanpa memilih mana yang layak dan sesuai dengan etika Islam. Hal ini menyebabkan krisis moral di kalangan umat Islam, baik terhadap pemuda, atau terhadap penguasa sekalipun."11

11 Mugy Nugraha, Milki Aan, dan Erta Wahyudin, Pendidikan Agama Islam, untuk kelas XI SMA, (Semarang: Karya Toha Putra), h. 187.

Walisongo, Volume 20, Nomor 1, Mei 2012 
Pernyataan tersebut dengan tidak ada penjelasan secara rinci dapat mendorong orang_untuk memusuhi Barat. Sebab seolah-olah, Barat-lah yang merusak generasi muda Islam. Kebencian terhadap Barat inilah yang menjadi salah satu motif kuat Bom Bali yang dilakukan oleh kelompok Imam Samudra. Simak pengakuan Imam Samudra:

"Berdasarkan niat atau target, jelas bom Bali merupakan jihād fi sabilillāh, karena yang jadi sasaran utama adalah bangsa-bangsa penjajah seperti AS dan sekutunya."12

\section{c. Bahan Ajar Kelas XII}

Untuk semester I, penulis membahas ayat-ayat al-Qur'an, salah satunya tentang anjuran toleransi yang terdapat QS. al-Kafirun [109]: 6, QS. Yunus [10]: 40-41 dan al-Kahfi [18]: 29. Kandungan ayat dijelaskan oleh penulis bahwa "umat Islam dituntut untuk menumbuhsuburkan sikap toleran tanpa mengorbankan keimanan". ${ }^{13}$ Ketika menjelaskan ayat 40-41 Surat Yunus, penulis menyatakan:

"(1) Umat manusia terbagi dua golongan dalam meyakini kebenaran alQur'an, yaitu ada yang mengimaninya dan ada pula yang mengingkarinya. (2) Islam agama yang lembut tidak memaksakan kehendak kepada orang lain."

Surat al-Kahfi ayat 29 menegaskan bahwa kebenaran datangnya dari Allah. Barang siapa yang ingin beriman maka berimanlah, dan barang siapa yang ingin ingkar kepada-Nya Allah pun tidak menghalanginya. Tidak ada paksaan dalam beragama, hanya saja orang-orang yang ingkar akan diminta pertanggungjawabannya dan akan mendapat balasan yang setimpal di akhirat kelak. ${ }^{14}$

Pernyataan ini mengisyarakan bahwa urusan manusia adalah mengajak semata dan urusan Allahlah yang akan memberikan balasan. Jika demikian sikap yang diambil maka akan memungkinkan pertemanan dengan semua orang dari segala perbedaan agama.

12 Imam Samudra, Aku Melawan Teroris, (Solo: Jazeera, 2004), h. 109.

13 Mugy Nugraha, Milki Aan, dan Erta Wahyudin, Pendidikan Agama Islam, untuk kelas XII SMA, (Semarang: Karya Toha Putra), h. 7.

14 Ibid., h. 15. 
Tidak dapat dipungkiri, subtansi ayat di atas mengajak toleransi dan menghargai perbedaan keyakinan. Namun ayat ini bila jatuh di tangan guru yang tidak pluralistik akan diplintir sedemikian rupa sehingga kehidupan harmonis tidak terwujud. Para pelaku radikalisme, bukannya tidak memahami ayat-ayat toleransi ini. Mereka lebih memilih ayat-ayat jihad yang tampak besar pahalanya, dibandingkan dengan ayat-ayat toleransi yang (sekilas) tidak menjanjikan pahala apapun.

Bab V dari buku SMA kelas XII adalah tentang munakahat. Kompetensi yang diharapkan adalah siswa dapat menjelaskan hukum Islam tentang nikah, talak, rujuk; siswa dapat menjelaskan hikmah nikah, talak dan rujuk; siswa dapat menjelaskan perkawinan menurut perundang-undangan tentang perkawinan di Indonesia dan siswa dapat menguraikan kompilasi hukum Islam tentang perkawinan di Indonesia.

Di dalam proses pembelajaran, sekalipun buku ini tidak menjelaskan secara spesifik penjelasan tentang "nikah beda agama," terdapat kemungkinan muncul pertanyaan kasus seperti ini oleh siswa. Jawaban guru terhadap kemungkinan adanya pertanyaan semacam ini dapat dijadikan sebagai tolok ukur bagaimana komitmen multikultur guru PAI. Jawaban yang kurang tepat akan menempatkan pemeluk agama lain sebagai "liyan" (Bhs Jawa, the others).

Salah satu bab dalam buku paket untuk semester II dijelaskan tentang perkembangan Islam di dunia. Penulis menjelaskan 28 negara Islam di benua Asia, menjelaskan 25 negara Islam di benua Afrika, Eropa, Amerika dan Australia. Sangat menarik uraian penulis tentang Islamophobia dan tragedi 11 September 2001. Penjelasan soal tragedi ini, jika tidak dilakukan hati-hati dapat memicu sikap anti-Barat di kalangan anak-anak muda Islam.

\section{Lembar Kerja Siswa (LKS)}

Di samping buku ajar untuk membantu siswa disediakan Lembar Kerja Siswa (LKS). LKS ini dimaksudkan untuk memperkaya, memperdalam dan ajang latihan siswa dalam mata pelajaran. Oleh karena itu, akan ditemukan pola penyusunan LKS yang sama, yaitu sebagian kecil berupa bacaan dan selebihnya berisi soal-soal pengayaan yang harus dikerjakan oleh siswa. Secara materi, tidak ada perbedaan antara buku paket dan LKS. Tetapi karena kebanyakan berupa soal-soal, maka isi dari LKS lebih tajam dalam meminta jawaban dari para siswa, apalagi bila soalnya dalam bentuk pilihan ganda. 
LKS disusun oleh guru yang tergabung dalam Musyawarah Guru Mata Pelajaran (MGMP). Dalam konteks PAI, yang menyusun LKS adalah MGMP PAI pada wilayah kerja masing-masing (bisa setingkat rayon atau kecamatan). Oleh karenanya, di setiap sekolah tidak sama sama LKS, baik dalam hal penyusun maupun penerbitnya.

Ada banyak guru PAI yang terlibat dalam penulisan LKS, diantaranya adalah Achmad Buchory, S.Sos, Domas Suryo SP, S.S, Gayatri, S.Si, Misbahul Hasanah, S.Si dan Puji Lestari. LKS yang diteliti adalah buku yang diterbitkan oleh CV. HaKa MJ Solo. Sebagaimana dimaklumi, Solo menjadi icon kota yang banyak melahirkan Muslim radikal. Di kota ini ditemukan puluhan organisasi Islam yang mengusung ideologi keras dalam penyebaran Islam.

Semuan guru PAI yang menjadi informan dalam penelitian ini menjawab dengan tegas bahwa di dalam buku paket dan LKS tidak terdapat materi yang mendorong siswa untuk berbuat radikal. Namun setelah dilakukan penelitian, terdapat elemen-elemen penjelasan dalam buku ajar yang dapat mendorong kearah radikalisme jika tidak dijelaskan dengan baik. Memang buku LKS ini semestinya tidak membangkitkan semangat radikalisme. Hanya saja ada beberapa pernyataan dan kalimat yang mungkin menimbulkan atau ditafsirkan dapat menimbulkan semangat radikalisme.

LKS untuk siswa SMA Semester I kelas X ditemukan kalimat yang meminta siswa untuk kegiatan mengisi portofolio, seperti berikut ini:

Portofolio: "Perkembangan Islam di duniai sedang pada masa yang tidak baik. Ideologi Barat sudah menyusup dikalangan Muslim di dunia. Bahkan Islam juga semakin dipojokkan oleh golongan Yahudi yaitu umat pembangkang. Negara-negara Islam juga sulit bersatu. Kepentingan negara sendiri diutamakan daripada kepentingan kolektif secara bersama. Masalah ini memang terjadi karena sistem kekhalifahan sudah runtuh. Padahal jelas dalam surah-surah di atas menjelaskan bagaimana kekhalifahan bahwa manusia sebagai pemimpin dunia dan harus bersatu. Nah, untuk mendalami permasalahan ini lakukanlah penelitian secara mendalam mengenai permasaalahan ini. Cari masalahnya dan analisislah dengan dalil-dalil al-Qur'an."15

Kalimat seperti di atas dapat mendorong munculnya radikalisme dengan mengangkat perlunya khiläfah sebagi sistem pemerintahan, padahal

15 Achmad Buchory, Domas Suryo, Gayatri, Misbahul Hasanah, dan Puji Lestari, LKS PAI, (Solo: CV. HaKa MJ Solo), h. 11. 
ayat 30 surat al-Baqarah tersebut berbicara tentang khalifah berkaitan tentang tugas manusia sebagai wakil Tuhan di muka bumi dan bukan khiläfah sebagai salah satu sistem pemerintahan. Tugas portofolio semacam ini dapat menggiring siswa kearah satu pemahaman perlunya sistem khilāfah dalam tatanan kehidupan.

Begitu pula ketika penulis LKS ini (pertemuan 9-10) mengharapkan aktivitas yang dilakukan siswa, mereka menyatakan:

"Portofolio: "Lunturnya keimanan manusia kepada Allah karena kurang sabarnya dalam menghadapi cobaan yang diberikan Allah SWT. Manusia hanya mencari sesuatu yang mudah saja dan meraih suatu kebahagiannya. Akibatnya banyak masyarakat di Indonesia menggunakan hal-hal yang bersifat mistis dan digolongkan ke dalam syirik atau menyekutukan Allah swt untuk mencari jalan pintas meraih kebahagian didunia. Di samping itu juga kebudayaan di Indonesia juga mendukung untuk mengerjakan hal-hal tersebut walaupun sebatas bid'ah. Nah coba buatlah makalah sederhana yang intinya membahas kasus yang dikemukakan."16

Tulisan ini menganggap kebudayaan di Indonesia dapat mendorong halhal yang bersifat bid'ah. Uraian tidak disertai bukti yang komplit atau setidaknya contoh, hingga membuat kesan kebudayaan di Indonesia bertentangan dengan Islam dan perlu ditinggalkan. Dalam konteks semangat pemurnian Islam, mistik dan bid'ah adalah ladang perjuangan Islam garis. Tugas semacam ini akan mendorong siswa untuk membandingkan dan mempertentangkan praktik kebudayaan yang dilakukan oleh umat Islam. Dengan tugas semacam ini, sudah pasti akan ikhtiläf (perbedaan pendapat) dalam masalah tahlil, manakiban, ziarah kubur dan seterusnya yang memang sangat dibenci oleh Islam garis keras.

Dalam Buku LKS untuk Kelas XI, semeter II, Bab 4, ditemukan banyak pertanyaan 'jebakan' yang harus dijawab oleh siswa. Misalnya, dalam materi menghindari dosa besa, penulis membuat pertanyaan: "9. Orang yang tidak taat kepada pemimpin (khalifah) disebut ................." Kata "pemimpin" lalu dijelaskan dalam kurung "khaliffah" mengesankan pentingnya ke-khalifah-an dalam sistem kepemimpinan, padahal sistem tersebut belum teruji dan tidak satu-satunya yang terbaik.

16 Ibid., 
Setelah dilakukan kajian untuk menjawab rumusan masalah elemenelemen radikalisme dalam pembelajaran PAI pada SMU, baik yang bersumber dari wawancara maupun buku ajar, ditemukan hal-hal sebagai berikut:

Pertama, unit-unit kerohanian Islam yang berada di sekolah-sekolah yang menjadi sampel penelitian ini berjalan dengan baik namun tidak ada jaminan steril dari elemen-elemen radikalisme Islam karena sebagian proses pembelajarannya diserahkan kepada pihak ketiga, yaitu ustadz-ustadz dari luar sekolah yang belum diketahui jelas latar belakang dan diduga berafiliasi dengan ormas/orpol tertentu yang mengusung ideologi NII dan mendorong pelaksanaan agama secara kaku dan tidak toleran. Kegiatan ekstra kerohanian Islam seperti mabit dan dawrah adalah suatu kegiatan penanaman ideologi Islam tertentu yang dapat berpotensi mendorong siswa untuk beragama secara kaku.

Kedua, di dalam buku paket dan LKS bermunculan berbagai statemen yang dapat mendorong siswa membenci atau anti terhadap agama dan bangsa lain. Tafsir soal Yahudi dan Nasrani, soal memilih pemimpin yang tidak boleh dari kalangan Yahudi dan Nasrani, kemunduran umat Islam disebabkan karena pengaruh Barat, dan nikah beda akan menjadi pintu masuk bagi munculnya sikap permusuhan terhadap agama lain. Sikap ini menjadi salah satu paham yang dijadikan landasan kaum radikal di kalangan umat Islam.

Ketiga, sebagian guru mengakui bahwa paham Islam radikal kemungkinan telah tersebar di kalangan siswa karena minimnya pengetahuan keagamaan mereka. Keikutsertaan siswa/i dalam kegiatan kerohanian Islam di luar kontrol guru PAI yang moderat, dapat mendukung pandangan asumsi penetrasi paham Islam radikal di lingkungan sekolah. Pengaruh radikalisme itu tidak hanya terhadap siswa tapi para guru PAI.

\section{Deradikalisasi Paham Islam Radikal}

Untuk mencegah penyebaran ideologi Islam radikal, deradikalisasi merupakan suatu keharusan dan mesti dilakukan dengan berbagai strategi di berbagai tempat. Pendidikan sebagai pusat pembelajaran siswa-siswi yang sedang berkembang dan mencari identitas adalah tempat strategis untuk menanamkan paham Islam moderat. 
Di dalam buku ajar (buku paket dan LKS) ditemukan dorongan substantif yang mengajak siswa/i untuk mengutamakan toleransi, demokrasi, penghormatan terhadap orang lain di satu sisi, dan di sisi lain ada pula pemahaman yang mendorong siswa/i bersikap anti-Barat, anti-Yahudi dan Nasrani dan lain sebagainya. Sisi yang saling bertentangan ini membutuhkan kebijaksanaan guru untuk menjelaskannya secara utuh dan komprehensif. Oleh karenanya, posisi guru sangat strategis untuk mempengaruhi pikiran para siswa/i, baik pengaruh positif maupun negatif. Untuk mengantisipasi penyebaran Islam radikal, para guru PAI mesti memiliki strategi untukpaling tidak-menghambatnya. Inilah yang dimaksud dengan strategi deradikalisasi paham Islam radikal.

Peneliti bertanya kepada guru-guru PAI bagaimana cara bapak atau ibu guru agar anak didik tidak terpengaruh dengan paham-paham radikal? Guruguru yang menjadi informan dalam penelitian memberikan jawaban yang variatif.

Azizah, guru PAI pada SMU 14 Semarang menyatakan bahwa guru harus mendoktrin bahwa sesama Muslim adalah saudara dan perbedaan adalah rahmat. Sedangkan Istiqomah menyatakan bahwa tuntutan/ajaran Islam (harus) dijelaskan sesuai dengan al-Qur'an dan Hadits.

Jawaban guru yang pertama merupakan strategi deideologisasi paham radikal, yakni dengan melakukan kontra-ideologi dan mendoktrin siswa/i bahwa Islam adalah agama damai yang menempatkan Muslim lain sebagai saudara sekalipun akidahnya menyimpang. Sedangkan jawaban guru yang kedua bersifat normatif di satu sisi, dan problematik di sisi yang lain. "Menjelaskan Islam sesuai al-Qur'an dan Hadits" pasti dilakukan oleh setiap umat Islam. Termasuk orang-orang yang berdakwah dengan cara kekerasan pun merasa tindakanya sudah sesuai dengan al-Qur'an dan Hadits.

Oleh karenanya, dalam pandangan peneliti, problem utamanya adalah minimnya akhlak dalam "menjelaskan Islam sesuai dengan al-Qur'an dan Hadits." Mengapa demikian? Pada dasarnya banyak aspek dalam agama yang kaku, misalnya aspek aqidah, ibadah dan hukum. Kekakuan mendorong seseorang untuk berpikir dan berperilaku keras. Munculnya benturan di kalangan umat Islam karena mereka kaku dalam tafsir dan penerapan hukum. Inilah yang menjadi sumber radikalisme Islam. Oleh karena itu, 
akhlak harus menjadi determinan penting dalam upaya hidup sesuai dengan al-Qur'an dan al-Sunnah.

Salah seorang guru PAI SMA 7 memberikan jawaban ketika ditanyakan tentang cara guru agak anak didik tidak gampang terpengaruh paham radikal. Menurutnya, seorang guru harus menyelipkan penjelasan tentang mazhab ulama. Jawaban ini menarik karena eksplisit didalamnya ada upaya untuk membuka horizon siswa bahwa Islam memang satu dan sumber pegangannya juga sama (al-Qur'an dan Hadits). Tetapi dalam hal memahami ajaran Islam, setiap ulama mungkin berbeda cara pandangnya. Inilah yang menyebabkan banyaknya mazhab-mazhab ulama dalam Islam.

Dengan memahami banyaknya aliran mazhab, peserta menjadi tidak fanatic hanya satu mazhab saja. Di samping itu, peserta didik juga menjadi toleran atas perbedaan pandangan yang mungkin terjadi di antara para ulama dan menganggap diri paling benar. Menurut hemat peneliti, cara ini menjadi salah satu strategi deradikalisasi yang penting agar siswa-siswi memiliki keluasan pandangan dalam memandang kebenaran.

Menurut Nikmah, seorang guru PAI SMA 5 Semarang, agar peserta didik tidak terpengaruh dengan dengan paham Islam radikal maka hakikat Islam harus dijelaskan secara utuh. Jika peserta didik ada yang mulai terpengaruh dengan paham radikal, maka guru harus melakukan dialog persuasif dengan siswa tersebut.

Jawaban salah salah satu guru mengisyaratkan perlunya tambahan jam pelajaran PAI dan keahlian guru PAI. Tidaklah mungkin dapat mengkaji hakikat Islam dengan waktu yang terbatas, guru yang tidak sebanding dengan jumlah siswa dan apalagi keahlian guru juga tidak mencukupi. Oleh karena itu, wajar bila anak didik banyak yang mengikuti tambahan pengajian di luar, dengan resiko mereka tidak mampu menyeleksi sendiri mana pengajian yang menyebarkan paham moderat atau malah paham radikal.

Siti Rohmah menjelaskan penting strategi ukhuwwah dalam upaya mengerem laju radikalisme di kalangan siswa. Baginya, hakikat beragama adalah untuk mendapatkan kedamaian dan ketenteraman dalam hidup. Jika hakikat tujuan beragama seperti ini, maka orang-orang yang menggunakan kekerasan untuk tujuan dakwah sama artinya dengan mereduksi hakikat beragama. 
Menurut pandangan Su'udi, salah seorang guru PAI di SMKN 8 Semarang, agar peserta didik tidak terpengaruh dengan pemahaman bahwa tindak kekerasan adalah melanggar hukum dan akan diberi sanksi. Oleh karena itu, reedukasi menjadi sangat penting peserta didik agar mereka tidak bertindak melawan hukum. Dalam konteks langkah-langkah apa yang perlu dilakukan jika anak-anak sudah terpengaruh dengan paham radikal, menurut pandangan Su'udi, perlu dilakukan bimbingan dan konseling bagi anak tersebut. Bimbingan dan konseling tersebut tentu harus menggunakan pendekatan keagamaan karena yang dihadapi adalah masalah-masalah yang berhubungan dengan keyakinan.

Menurut Abdul Aziz, guru PAI pada SMU Sultan Agung, untuk mengantisipasi paham radikal harus menyadarkan kepada anak-anak dengan pemahaman secara luas dan tidak secara parsial. Agama Islam sesungguhnya agama yang cinta damai, mengutamakn toleransi, akhlak, meskipun sejarah Islam diwarnai dengan peperangan dan konflik-konflik. Perang dan konflik harus dijelaskan secara utuh konteksnya bahwa Islam itu tidak seluruhnya demikian. Umat Islam waktu berperang untuk membela diri karena ancaman dariluar.

Menurut Aziz, dulu sempat ada anak yang pernah ikut kegiatan Islam radikal seperti itu. Mereka berpikir mujahidin akan menang (dalam konteks perang di Afghanistan). Kemudian pihak sekolah berkomunikasi dengan orang tua, termasuk menjalaskan tentang organisasi-organisasi Islam keras yang sudah diamati oleh TNI/Polri. Pihak sekolah dan khususnya guru, menjelaskan dengan utuh bahwa Islam tidak pernah mengajarkan kekerasan. Kemudian sampai saat ini, belum (belum ditmukan lagi siswa yang) berperilaku radikal.

Untuk mengawasi radikalisme berkembang di sekolah, menurut Aziz, pihak sekolah memberikan wawasan, penyadaran, pemahaman (yang benar) kepada yang bersangkutan. Hal ini juga menuntut peran serta orang tua untuk mengawasi perilaku anak-anaknya. Tanpa orang tua, upaya deradikalisasi paham radikal (tidak) akan maksimal. Jika ada yang mulai terpengaruh, pihak sekolah akan mencari tahu siapa dia, bagaimana pikiran dan perilaku, aliran, dan pergaulannya dengan siapa saja sehingga menjadikan anak seperti ini. 
Menurut Ahmad Dhuha, guru PAI pada SMA Kesatrian Semarang, jika ditemukan peserta didik yang mulai terpengaruh dengan ajaran radikal maka pihak sekolah akan memanggil anak itu untuk diajak bicara terkait agama. Setelah dilakukan dialog lalu muncul pikiran yang aneh-aneh, berarti berarti ia sudah terindikasi radikal. Langkah berikutnya adalah melakukan tracking anak yang terindikasi radikal itu dengan cara bertanya kepada guru-guru yang lain, termasuk menanyakan mereka dapat ajaran dari mana sehingga menyebabkan anak menjadi radikal seperti ini. Setelah semua informasi diketahui, guru agama dan pihak sekokah bersama keluarga pihak keluarga duduk bersama untuk membicarakan anak didik yang terkena paham radikal tersebut.

Guru PAI dan pihak sekolah pada umumnya memiliki keterbatasan untuk mengawasi kegiatan keagamaan siswa-siswi, baik yang ada di dalam sekolah apalagi yang di luar sekolah. Hampir semua guru PAI yang menjadi informan penelitian ini mengawasi, tetapi faktanya tidak mungkin dilakukan secara maksimal. Jawaban-jawaban mereka berkisar pada: "pasti mengawasi, kadang-kadang mengawasi, di dalam sekolah diawasi dan di luar sekolah tidak." Hal ini mengindikasikan bahwa lemahnya pengawasan guru terhadap kegiataan keagamaan siswa. Salah satu penyebabnya karena tidak sebanding antara jumlah siswa dengan ketersediaan guru.

Salah satu indikasi paham Islam radikal adalah kecamannya terhadap tata kelola kehidupan yang tidak atas nama agama (syariah). Mereka sering membenturkan antara ke-Indonesiaan dengan ke-Islaman. Mereka juga merasa tidak memiliki Negara dan tidak berkewajiban membela keutuhan Negara kesatuan Republik Indonesia (NKRI). Nafsu mereka justru ingin memecah Indonesia menjadi Negara-negara kecil dengan menerapkan syariat Islam. Oleh karenanya, perlu ditingkatkan nasionalisme peserta didik sebagai salah satu cara untuk menangkal paham radikal. Kepada para guru PAI, ditanyakan kepada mereka bagaimana caranya untuk membuat peserta didik memiliki nasionalisme yang tinggi?

Menurut Abdul Aziz, guru PAI SMA Sultan Agung Semarang, peserta didik harus diingatkan kembali tentang perjuangan para ulama' dan kiai dalam merebut kemerdekaan dan mengisi kemerdekaan di awal pendirian Indonesia. Dasar Negara Islam memang sempat diperdebatkan dalam Sidang Konstitusi penentuan dasar Negara, tetapi pilihan mereka tetap adalah 
Pancasila sebagai payung besar rakyat Indonesia yang beragam etnis dan agamanya.

Menurut Ahmad Duha, guru PAI SMA Kesatrian, salah satunya dengan adanya upacara bendera. Kedua, memberikan pemahaman sejarah berdirinya bangsa ini bahwa kemerdekaan bangsa ini bukan pemberian melainkan perjuangan. Ketiga, perjuangan ini banyak memakan korban. Keempat, bangsa ini utuh karena ada persatuan. Jadi, menjaga persatuan dan kesatuan dengan mengingat sejarah bangsa menjadi modal bangsa agar Indonesia tetap utuh.

Menurut Sri Istiqomah, untuk menjaga dan meningkatkan nasionalisme, para siswa harus rela berkoban untuk bangsa ini. Artinya, kepentingan pribadi yang bersifat keagamaan ditekan dan menjaga kemaslahan umum diutamakan. Sampai hari ini, mayoritas warga bangsa menjadikan Pancasila sebagai dasar Negara bukan Islam. Sebab faktanya, Indonesia memiliki bermacam suku dan agama sehingga kalau dipaksakan dengan dasar Islam akan menyebabkan Indonesia pecah.

\section{Strategi Deradikalisasi}

Lahirnya kelompok-kelompok Islam yang keras, tidak toleran terhadap perbedaan, mengaku paling benar sendiri dan kadang kala melakukan teror, menimbulkan keprihatinan di masyarakat, termasuk juga dunia pendidikan. Kelompok Islam seperti itu, yang dalam penelitian ini disebut Islam radikal, jumlahnya makin banyak sekalipun tidak selalu melakukan teror. Sebagai bukti, makin mudah ditemukan kelompok Islam yang terang-terangan ingin mengganti dasar negara Pancasila dengan dasar agama, tidak sedikit orang yang gampang menyebut orang lain sebagai kafir, țāghūt, ahli bid'ah, ahli neraka dan seterusnya.

Pada sisi yang lain, serbuan Islam transnasional dari Timur Tengah yang membawa ideologi Islam keras sangat mengkhawatirkan masyarakat dan pemerintah. Masyarakat khawatir karena keragaman paham dan pandangan keagamaan dicap sebagai penyimpangan ajaran Islam. Hal ini memicu terjadi benturan paham bahkan fisik antar anggota masyarakat. Aksi teror yang didasari oleh paham agama telah mendelegitimasi peran negara dalam mewujudkan ketertiban. Apalagi, pelaku radikalisme juga menganggap negara Indonesia negara kafir, thaghut dan tidak layak diikuti. Aksi teror, terutama 
dalam bentuk bom bunuh diri, mendorong pemerintah untuk membuat kebijakan tentang perang melawan terorisme.

Atas dasar itu, maka pemerintah membentuk Badan Nasional Penanggulangan Terorisme (BNPT) pada tahun 2010 (Perpres No. 46 Tahun 2010). Tugas utama BNPT adalah penanggulangan terorisme, meliputi pencegahan, perlindungan, deradikalisasi, penindakan, dan penyiapan kesiapsiagaan nasional (Ps 2). Sedangkan salah satu fungsinya adalah koordinasi dalam pencegahan dan pelaksanaan kegiatan melawan propaganda ideologi radikal di bidang penanggulangan terorisme (Ps 3). Atas dasar itu, maka deradikalisasi telah menjadi kebijakan nasional yang harus dilakukan, termasuk meminta peran serta dari masyarakat.

Disadari bahwa tidak semua umat Islam menyetujui 'proyek' deradikalisasi. Sebagai contoh, Sekjen Forum Umat Islam (FUI), M. Al-Khaththath menganggap deradikalisasi agama sebagai ancaman dan teror baru bagi umat Islam. Ada juga yang menanggap deradikalisasi merupakan proyek untuk mengamputasi syariah. Hal itu sangat mungkin terjadi, bila deradikalisasi dilakukan dengan serampangan dan tanpa memiliki keahlian. Oleh karena itu, deradikalasi harus diawasi dan dilakukan, terutama oleh masyarakat sendiri dan khususnya di kalangan sekolah.

Guru-guru PAI dilibatkan karena posisinya yang strategis, tinggal di tengah-tengah sekolah dan masyarakat serta bergelut dengan problem keagamaan peserta didik. Guru-guru PAI selama ini, disadari atau tidak, telah melakukan pencegahan radikalisme paham beragama, dalam bentuk anjuran, ajakan bahkan nasehat kepada para peserta didik untuk hidup rukun, toleran dan tidak menganggap paling benar sendiri. Sekalipun demikian, harus diakui bahwa strategi yang dilakukan oleh guru-guru PAI tentang deradikalisasi Islam belum utuh sepenuhnya, terutama yang berkaitan dengan detail jenis dan program deradikalisasi.

Deradikalisasi merupakan kerja lanjutan setelah diketahui akar radikalismenya. Tetapi deradikalisasi juga dapat dimaksudkan untuk langkah antisipasi sebelum radikalisme terbentuk. Penelitian ini sejatinya adalah mencari formula antisipatif terhadap elemen-elemen radikalisme yang mungkin ada dalam proses pembelajaran PAI. Elemen-elemen radikalisme itu ternyata ada sekalipun kecil skalanya, baik dalam buku ajar maupun kegiatan pembelajaran ekstra kerohanian Islam. Jangan dilupakan bahwa salah satu sekolah yang menjadi objek kajian ini telah mendapati salah satu peserta 
didik terindikasi paham radikal. Sekalipun itu terjadi pada masa dulu dan berskala kecil, hal ini harus diwaspadai agar tidak terulang kembali.

Di samping mengetahui elemen dan akar radikalisme, strategi deradikalisasi juga perlu diketahui agar 'obat' sesuai dengan indikasi penyakitnya. Selanjutnya tujuan deradikalisasi perlu dirumuskan secara pasti, yakni mengembangkan Islam moderat. Hubungan kerja antara akar radikalisme, strategi deradikalisasi dan tujuan deradikalisasi, dapat digambarkan dalam segitiga deradikalisasi (triangle of deradicalizaton) berikut ini:

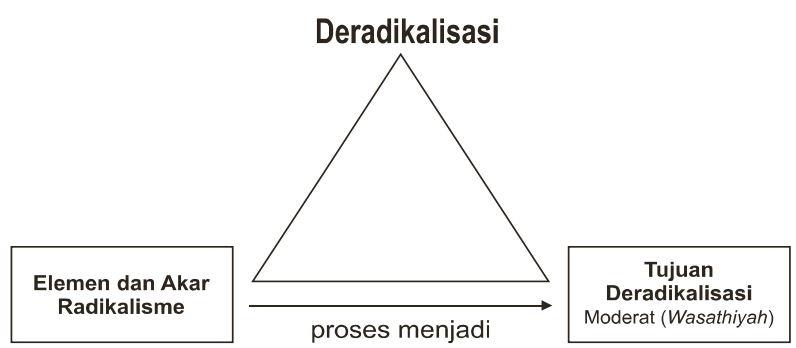

Gambar 1.

Triangle of Preventive and Preservative Deradicalization

Dari gambar di atas dapat dipahami bahwa deradikalisasi dapat dimulai langsung dari elemen maupun akar radikalisme yang dimaksudkan sebagai deradikalisasi pencegahan (preventive deradicalization) dan pemeliharaan (preservative deradicalization) Islam moderat. Dengan model ini, deradikalisasi bersifat proaktif dan tidak menunggu sampai terjadi, misalnya aksi terorisme. Selain itu, model yang pertama juga dapat digunakan untuk deteksi dini apakah seseorang atau sekelompok orang berpotensi berpikir dan bertindak radikal. Aktor yang terlibat dalam deradikalisasi model yang pertama ini adalah negara, pemerintah dan seluruh lapisan masyarakat. Dalam konteks dunia pendidikan, pihak yayasan, sekolah, guru dan orang tua menjadi aktor utama

Sedangkan isi atau program deradikalisasinya, meliputi hal-hal sebagai berikut: (1) re-edukasi (memahami Islam lebih utuh); (2) kampanye ukhuwwah islāmiyyah dan anti radikalisme. 
Di samping itu, deradikalisasi juga dapat dilakukan setelah seseorang menjadi radikal (curative deradicalization). Model ini bersifat menyembuhkan bagi pelaku radikalisme, baik sebelum maupun setelah terjadi aksi radikal (teror).

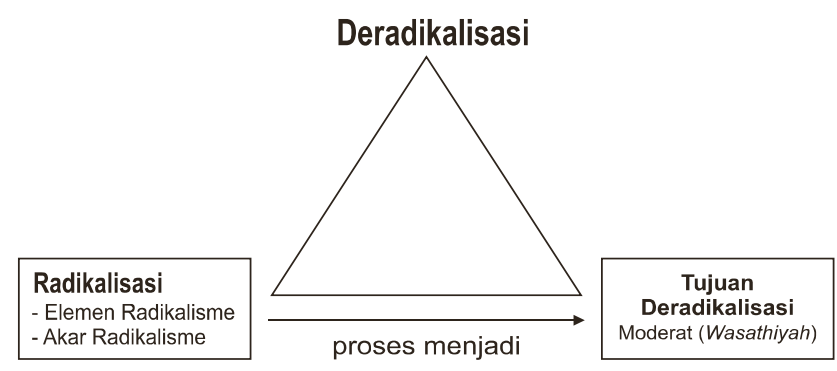

Gambar 2.

Triangle of Deradicalization

Dari gambar di atas dapat dipahami dua hal. Pertama, seseorang yang menjadi radikal dalam pikiran dan paham keagamaan. Mereka membutuhkan strategi dan program deradikalisasi yang berbeda. Selain membutuhkan program deradikalisi gambar no. 1, juga dibutuhkan langkah-langkah yang lain, seperti: (1) dialog intensif; (2) pendekatan konseling dan psikologis. Aktor yang terlibat dalam deradikalisasi model yang pertama ini adalah guru PAI, pihak sekolah dan orang tua.

Kedua, seseorang yang sudah melakukan tindakan teror, yang berhasil ditangkap, diadili dan dipenjarakan. Dalam hal ini, pemerintah sudah memiliki strategi deradikalisasi yang dilakukan oleh BNPT, yaitu re-edukasi, rehabilitasi, reintegrasi dan resosialisasi. Menurut ICG, deradikalisasi di atas masih perlu ditambah dengan reformasi penjara atau Lembaga Pemasyarakatan. Sedangkan isi atau program reedukasi pelaku teror dapat mengacu kebijakan pemerintah dalam menangani narapidana terorisme (hal ini tidak menjadi konsen penelitian ini).

Perlu diketahui bahwa pandangan guru-guru PAI tentang deradikalisasi Islam radikal masih berupa konsep (ada yang masih sangat mentah) dan tentu tidak dapat langsung diterapkan (non-applicable). Diperlukan kajian lain yang dapat menghasilkan modul atau kurikulum deradikalisasi yang 
lengkap dan implementatif. Misalnya strategi dialog, bagaimana harus dilakukan dan bagaimana tahap-tahapnya, begitu pula dengan strategi bimbingan dan konseling.

\section{E. Kesimpulan}

Setelah dilakukan kajian ditemukan kesimpulan sebagai berikut:

Pertama, sebagian guru mengakui bahwa paham Islam radikal kemungkinan telah tersebar di kalangan siswa karena minimnya pengetahuan keagamaan mereka. Keikutsertaan siswa/i dalam kegiatan kerohanian Islam di luar kontrol guru PAI yang moderat, dapat mendukung pandangan asumsi penetrasi paham Islam radikal di lingkungan sekolah. Pengaruh radikalisme itu tidak hanya terhadap siswa tapi para guru PAI.

Kedua, unit-unit Kerohanian Islam (Rohis) yang berada di sekolahsekolah yang menjadi sampel penelitian ini berjalan dengan baik namun tidak ada jaminan steril dari elemen-elemen radikalisme Islam karena sebagian proses pembelajarannya diserahkan kepada pihak ketiga, yaitu ustadz-ustadz dari luar sekolah yang belum diketahui jelas latar belakang dan diduga berafiliasi dengan ormas/orpol tertentu yang mengusung ideologi NII dan mendorong pelaksanaan agama secara kaku dan tidak toleran. Kegiatan ekstra kerohanian Islam seperti mabit dan dawrah adalah suatu kegiatan penanaman ideologi Islam tertentu yang dapat berpotensi mendorong siswa untuk beragama secara kaku.

Ketiga, di dalam buku paket dan LKS bermunculan berbagai statemen yang dapat mendorong siswa membenci atau anti terhadap agama dan bangsa lain. Tafsir soal Yahudi dan Nasrani, soal memilih pemimpin yang tidak boleh dari kalangan Yahudi dan Nasrani, kemunduran umat Islam disebabkan karena pengaruh Barat, dan nikah beda agama akan menjadi pintu masuk bagi munculnya sikap permusuhan terhadap agama. Sikap ini menjadi salah satu akar paham radikalisme di kalangan umat Islam.

Keempat, pada dasarnya deradikalisasi dapat dimulai, baik elemen maupun akar radikalisme. Dalam penelitian ini disimpulkan deradikalisasi pencegahan (preventive deradicalization) dan pemeliharaan (preservative deradicalization) Islam moderat. Dengan model ini, deradikalisasi bersifat proaktif dan tidak menunggu sampai terjadi aksi terorisme. Strategi deradikalisasi yang dilakukan oleh guru-guru PAI adalah: (1) re-edukasi (me- 
mahami Islam lebih utuh); (2) kampanye ukhuwwah islämiyyah dan anti radikalisme. Di samping itu, deradikalisasi juga dapat dilakukan setelah seseorang menjadi radikal (curative deradicalization). Model ini bersifat menyembuhkan bagi pelaku radikalisme, baik sebelum maupun setelah terjadi aksi radikal (teror). Selain membutuhkan strategi deradikalisi yang pertama, juga dibutukan langkah-langkah yang lain, seperti a) dialog intensif; b) pendekatan konseling dan psikologis. Aktor yang terlibat dalam deradikalisasi model yang pertama ini adalah guru PAI, pihak sekolah dan orang tua. Jika seseorang sudah melakukan tindakan teror, yang berhasil ditangkap, diadili dan dipenjarakan, maka strategi deradikalisasi mengacu kebijakan pemerintah yang dilakukan oleh BNPT.[w] 


\section{BIBLIOGRAFI}

Abbas, Nasir, "Memberdayakan Potensial Masyarakat dalam Pemberantasan Terorisme," dalam Seminar Nasional Menuju Kerangka Hukum Pemberantasan Terorisme yang Komprehensif, kerjasama Lazuardi Birru dan BNPT, Jakarta, 23 Juni 2011.

Achmad Buchory, Domas Suryo, Gayatri, Misbahul Hasanah, dan Puji Lestari, LKS PAI, Solo: CV. HaKa MJ Solo.

Ali, Muhammad, Teologi Pluralis-Multikultural, Jakarta: Kompas, 2003.

Ansyar, Muhammad, Dasar-dasar Pengembangan Kurikulum, Jakarta: Dirjen PTPPLPTK Depdikbud, 1989.

Asy'arie, Musa, Manusia Pembentuk Kebudayaan dalam al-Qur'an, Yogyakarta: LESFI, 1992.

Atmasasmita, Romli, "Deradikalisasi dan Tindak Pidana Terorisme," Harian Seputar Indonesia, 25 April 2011.

Azizy, A. Qodri A., Pendidikan [Agama] untuk Membangun Etika Sosial, Semarang: Aneka Ilmu, 2003.

Azra, Azyumardi, "Akar Radikalisme Keagamaan: Peran Aparat Negara, Pemimpin Agama dan Guru untuk Kerukunan Umat Beragama," makalah dalam diskusi "Memperkuat Toleransi Melalui Sekolah," The Habibie Center, Hotel Aston, Bogor, 14 Mei 2011.

Pergolakan Politik Islam, dari Fundamentalis, Modernisme hingga PostModernisme, Jakarta: Paramadina, 1996.

Baidhawi, Zakiyudin, Pendidikan Agama Berwawasan Multikulturalisme, Jakarta: Gelora Aksara Pratama, 2008.

Bakri, Syamsul, "Islam dan Wacana Radikalisme Agama Kontemporer," Jurnal DINIKA Vol. 3 No. 1, Januari 2004.

Bubalo, Anthony dan Greg Fealy, Jejak Kafilah: Pengaruh Radikalisme Timur Tengah di Indonesia, terj. Akh. Muzakki, Bandung: Mizan, 2007

Davis, Michael, "Laskar Jihad and the Political Position of Conservative Islam in Indonesia," dalam Contemporary Southeast Asia, Vol. 24, 2002.

Direktorat Pendidikan Agama Islam pada Sekolah, Standar Isi dan Standar Kelulusan Pendidikan Agama Islam, Jakarta: Depag, 2007. 
Fanani, Ahmad Fuad, "Radikalisme dan Pembiaran," dalam Kompas, 30 April 2011.

Fealy, Greg and Virginia Hooker (ed.), Voices of Islam in Southeast Asia: A Contemporary Sourcebook, Singapore: ISEAS, 2006.

Golose, Petrus Reinhard, Deradikalisasi Terorisme, Jakarta: YPKIK, 2009.

Hasan, Noorhadi, Laskar Jihad: Islam, Militancy and the Quest for Identity in PostNew Order Indonesa, (Utrecht: Faculteit der Letteren en International Institute for the Study of Islam in the Modern Wolrd, 2005).

Hasil-hasil Semiloka Nasional "Mendayagunakan Potensi Nasional dalam Rangka Penanggulangan Terorisme di Indonesia," tanggal 27 dan 28 Oktober 2009 di Sespim Polri. Dimuat dalam http://www. komisikepolisianindonesia.com. Akses tanggal 25 Agustus 2011.

Hendropriyono, AM., Terorisme Fundamentalisme Kristen, Yahudi, Islam, Jakarta: Kompas, 2009.

International Crisis Group, "Deradikalisasi dan Lembaga Pemasyarakatan di Indonesia, “Asia Report N¹42 - 19 November 2007.

Ismail, Noor Huda, Temanku Teroris, Bandung: Mizan Publika, 2010.

Jabiri, Muhammad Abid, Agama, Negara dan Penerapan Syari'ah, Yogyakarta: Pustaka Pelajar, 2001.

Juergensmeyer, Mark, Teror Atas Nama Tuhan: Kebangkitan Global Kekerasan Agama, terj. Sadat Ismail (Jakarta: Nizam Press, 2002).

Mugy Nugraha, Milki Aan, dan Erta Wahyudin. Pendidikan Agama Islam kelas X, XI dan XII SMA, Semarang: Karya Toha Putra.

Makassary, Ridwan, dkk, Benih-benih Radikalisme di Masjid, Jakarta: CSRC UIN Jakarta, 2010.

Mbai, Ansyaad, makalah dalam Seminar Nasional "Menuju Kerangka Hukum Pemberantasan Terorisme yang Komprehensif, kerjasama Lazuardi Birru dan BNPT, Jakarta 23 Juni 2011.

Muhaimin, Konsep Pendidikan Islam: Sebuah Telaah Komponen Dasar Kurikulum, Solo: Ramadhani, 1991.

Mujib, Abdul dan Jusuf Mudzakkir, Ilmu Pendidikan Islam, Jakarta: Kencana, 2008.

Mulyadi, Sukidi, "Violence under the Banner of Religion: The Case of Laskar Jihad and Laskar Kristus," Studia Islamika, Vol. 10, 2003.

Nitibaskoro, Tb. Roni R, "Deradikalisasi Radikalisme Bermotif Agama dalam Perspektif Kriminologis," dalam makalah lokakarya dalam rangka Hari Bhayangkara ke-65, 
tanggal 23 Juni 2011. http://www. komisikepolisianindonesia.com, akses tanggal 20 Agustus 2011.

Qardhawi, Yusuf, Islam Radikal: Analisis terhadap Radikalisme dalam Berislam dan Upaya Pemecahannya, terj. Hawin Murtadho, Solo: Era Intermedia, 2004.

Rahmat, M. Imdadun, Arus Baru Islam Radikal: Transmisi Revivalisme Islam Timur Tengah ke Indonesia, Jakarta: Penerbit Erlangga, 2005.

Salim, Arskal dan Azyumardi Azra, "Introduction: The State and Shari'a in the Perspective of Indonesian Legal Politics," dalam Sharia and Politics in Modern Indonesia, ed. Arskal Salim and Azyumardi Azra, Singapore: Institute of Southeast Asian Studies, 2003.

Samudra, Imam, Aku Melawan Teroris, Sukoharjo: Jazeera, 2006.

Sidik, Jafar M., "Terorisme, Semiotika dan Bahasa Indonesia" dalam Kompas, 6 Oktober 2010.

Soetapa, Djaka, "Asal-usul Gerakan Fundamentalisme," dalam Ulumul Qur'an, Vol. IV, No. 3, 1993.

Tafsir, Ahmad, Metodik Khusus Pendidikan Agama Islam, Bandung: Remaja Rosdakarya, 1990.

hoha, M. Chabib, Pendidikan Islam, Yogyakarta: Pustaka Pelajar, 1996.

Thohir, Mudjahirin, "Deradikalisme Keagamaan dalam Perspektif Sosial-Budaya" dalam Seminar Nasional, Deradikalisasi Agama melalui Peran Muballigh di Jawa Tengah, Fak. Dakwah IAIN Walisongo, 20 Juli 2011.

Turmudzi, Endang (ed.), Islam dan Radikalisme di Indonesia, Jakarta: LIPI Press, 2005.

Zada, Khamami, Islam Radikal: Pergulatan Ormas-ormas Islam Garis Keras di Indonesia, Bandung: Teraju, 2002.

Walisongo, Volume 20, Nomor 1, Mei 2012 
